\title{
Postural Disorders and Muscle Power in Primary School Children
}

\author{
Saša Bubanj ${ }^{1}$, Stefan Đorđević ${ }^{1}$, Saša Milenkovići ${ }^{1}$, Ratko Stanković ${ }^{1}$, Mikica Vidojević ${ }^{2}$ \\ Milan Đokić ${ }^{3}$
}

${ }^{1}$ University of Niš, Faculty of Sport and Physical Education, Niš, Serbia

${ }^{2}$ Health Center of Knjaževac, Knjaževac, Serbia

${ }^{3}$ Municipality of Knjaževac, Knjaževac, Serbia

\begin{abstract}
SUMMARY
The aim of the research was to contribute to better understanding of the correlation between postural disorders and muscle power in primary school children. The sample of respondents consisted of 1,120 children, aged 7 to 12 years ( 549 boys and 571 girls) from the territory of the municipality of Knjaževac. In the assessment of the spinal column status, the device "Spinal Mouse" (Switzerland) was used, while in the analysis of the status of the feet, the podoscope "Pedic" (Hungary) was used. A handheld dynamometer "Lafayette" (USA) and tensiometric force platform "Vernier Force Plate" (USA) were used in the analysis of muscle power. Spinal column and feet status were measured in the static condition, with children being in the upright standing position. Muscle power status was measured in both static (a clinician was applying muscle force to the dominant upper extremity of a child trying to overcome or "break" the child's muscle resistance) and dynamic conditions (Counter Movement Jump). Descriptive statistics and correlation analysis were used in data processing by the means of the SPSS software version 24. Results revealed poor postural and muscle power status, and correlations suggesting to possible kinetic chain reaction causing the disruption of the normal postural status in primary school children. Determined postural disorders are characterized by the early functional stage that can be reduced by appropriate corrective exercise programme application and augmented level of proper physical activity. Those programmes and activities are being guided and implemented by physicians and PE teachers in the municipality of Knjaževac.
\end{abstract}

Key words: postural status, musculoskeletal disorders, corrective exercises, primary school children

Corresponding author:

Saša Bubanj

e-mail: bubanjsale@gmail.com 


\section{INTRODUCTION}

Disturbed postural status in school children may have favorable outcome in case of early detection, systematic monitoring and corrective treatment including specific rehabilitation, swimming and follow-up activities (1).

Preventive programmes should aim to augment regular participation of pre-school children in different sports and physical activities and to organize systematic check-ups at least once at the annual level. Hence, prevention of postural disorders in school children is of the multidisciplinary nature and comprises strong cooperation between parents, (physical education-PE) teachers in kindergartens, and physicians, involving public entities, sport clubs and health centers.

Not less significant is the postural status evaluation methodology. Namely, although non-invasive, subjective visual inspection associated with invasive radiological examinations are, even today, largely present protocols worldwide.

Last two decades are characterized by great scientific step forward in non-invasive clinical examination, by the development of surface topography computational techniques that enable clinical examination of the large number of individuals (2).

However, non-invasive clinical examination of the large cohorts should be characterized not only by rapid and simple procedures, but by high reliability of diagnoses as well (3).

The key factor in forming and maintaining good posture in children are the skeletal muscles. Skeletal muscles represent an active part of the apparatus for movement, and their weakness, as well as their excessive and unilateral load, lead to a variety of disorders of the spinal column, upper and lower extremities (4).

Due to muscular imbalance, individual body segments take specific positions leading to the occurrence of the postural disorders in children (5).

The aim of the research is to contribute to a better understanding of the correlation between postural disorders and muscle power in primary school children.

\section{METHODS}

\section{The sample of the respondents}

The sample of the respondents consisted of 1,120 children ( 549 boys and 571 girls), free of any kind of congenital or acquired disorders, aged 7 to 12 , from the territory of the municipality of Knjaževac, Serbia. Assessment was carried out during the school year 2016/17. Parental permission was obtained prior to testing.

\section{Measurement methodologies}

Non-invasive measurement methodology, including modern computerized measuring instruments with associated softwares, was in use: „Spinal Mouse" (Idiag, Fehraltdorf, Switzerland, www.idiag.ch) in the assessment of the spinal column status in three planes (6). It supplies reliable data to support a clinical evaluation $(7,8)$; podoscope "Pedic" (Hungary) in the assessment of the feet status; hand-held dynamometer "Lafayette" (USA) in the assessment of the muscle power status of the upper extremities and tensiometric force platform "Vernier Force Plate" (USA) in the assessment of the muscle power status of the lower extremities.

\section{Classification of spinal disorders}

According to the Pediatric Orthopaedic Society of North America and US Preventive Services Task Force, scoliosis is defined as a complex 3D deformity of the spinal column. It is characterized by: 1) Cobb angle greater than 10 degrees as seen in the frontal plane; 2) decreased thoracic kyphosis in the sagittal plane; 3) posterior rib prominence caused by rotation of the vertebrae in the horizontal plane $(9,10)$. Hyperkyphosis is characterized by Cobb angle greater than 40 degrees as seen in the sagittal plane (9). Using the Cobb's method and by measurement of the region between the superior endplate of the L1 to the superior endplate of the S1, it was determined that an optimal lordosis angle ranged from 30 degrees up to even 80 degrees (11).

Hence, Cobb angle obtained via radiologic measurement and calculated based on the inclination of the vertebral body represents the gold standard in measuring spinal disorders. On the other hand, the values of kyphotic, lordotic and scoliotic curvature obtained via "Spinal Mouse" instrument represent the pandam of the Cobb angle, but cannot be fully identified with it. Namely, in the actual case of surface topografy, the value of an angle is calculated based on the position of the posterior elements of the vertebrae. 
Considering research methodology (non-invasive surface topography), and sample of respondents (children), the following reference values were applied in relation to spinal disorders of children aged 7 to 12 from the municipality of Knjaževac (12):

Hyperkyphosis of the first degree (from 45 degrees to 55 degrees) and of the second degree (from 55 degrees to 65 degrees).

Hyperlordosis of the first degree (from 35 degrees to 45 degrees) and of the second degree (from 45 degrees to 55 degrees).

Scoliosis of the first degree (from 5 degrees to 15 degrees) and of the second degree (from 15 degrees to 25 degrees).

\section{Procedures}

Spinal column and feet status are measured in static conditions, with children being in the upright standing position. Muscle power status was measured with children being: 1) in the upright standing position while the clinician was applying force to the dominant upper extremity of a child, trying to overcome or "break" the child's resistance (static condition); 2) and with children performing Counter Movement Jump without arms' swing-CMJ (dynamic condition) (13). Children made three attempts within each of the muscle power status tests, and the best one counted. Children were barefoot and in underwear during the assessment.

\section{The sample of the variables}

Morphological status:

Body mass (BM in $\mathrm{kg}$ ) and body height (BH in $\mathrm{m}$ ).

Spinal column status:

Hyperkyphosis (KYP in deg); hyperlordosis (LOR in deg); and scoliosis (SCO in deg).

Feet status:

Right foot (RF in degree of the disorder from 2 to 4 ) and left foot (LF in degree of the disorder from 2 to 4 ).

Muscle power status:

a) In static conditions: absolute power of the biceps brachii muscle (APBB in $\mathrm{kg}$ ); relative power of the biceps brachii muscle (RPBB in \%); absolute power of the quadriceps femoris muscle (APQF in $\mathrm{kg}$ ); and relative power of the quadriceps femoris muscle (RPQF in \%).

b) in dynamic conditions: maximum muscle power in the concentric phase of the CMJ (Fmax in
$\mathrm{N}$ ); index of the explosive muscle power of the CMJ (IEP in $\mathrm{N} / \mathrm{ms}$ ); and reactivity coefficient of the CMJ [(RC in $\left.\mathrm{N} /\left(\mathrm{ms}^{*} \mathrm{~kg}\right)\right]$.

\section{Data processing}

Data are processed by the means of the descriptive statistics and correlation analysis, using SPSS software version 24 . To examine the influence of the muscle power on the spinal column and feet status, the Spearman correlation coefficient was used since the distribution of the values in most of the observed measurements significantly deviated from the normal distribution (confirmed by the Kolmogorov Smirnov test).

\section{RESULTS}

The results of the descriptive statistics shown in Tables 1 and 2 and Graph 1 indicate that the younger school age children from the territory of the municipality of Knjaževac most frequently suffer from postural disorders related to flat feet and scoliosis, followed by hyperlordosis, and finally, hyperkyphosis.

Correllation analysis

Based on the Spearman correlation coefficient, the following results were obtained:

Positive correlations

1) KYP with APBB (Rs .193**, sig .000); with APQF (Rs .158**, sig .000); with Fmax (Rs .157**, sig .000); with IEP (Rs 103**, sig .001);

2) LOR with APQF (Rs .129**, sig .000); with APBB (Rs .110**, sig .000);

3) LF with APQF (Rs .063*, sig .037);

4) RF with APQF (Rs .076*, sig .011).

Negative correlations

1) KYP with RPQF (Rs -.097**, sig .001); and with RPBB (Rs -.072*, sig .017);

2) LF with RPBB (Rs -.144**, sig .000); with RPQF (Rs -.064*, sig .034); and with RC (Rs -.060*, sig .047);

3) RF with RPBB (Rs -.153**; sig .000); with RPQF (Rs -.080**, sig .008); and with RC (Rs -.072*, $\operatorname{sig} .018)$.

The results of the correlation analysis shown above indicate:

1) a significant positive correlation between: a) sagittal postural status (KYP and LOR) and muscle power status in static conditions (APBB and APQF); b) sagittal postural status (KYP) and muscle 
Table 1. Descriptive statistics of the total sample $(N=1,120)$

\begin{tabular}{l|l|c|c|c|c}
\hline \hline & $\mathrm{N}$ & Minimum & Maximum & Mean & SD \\
\hline BM (in kg) & 1120 & 16.40 & 106.70 & 36.40 & 11.99 \\
\hline BH (in m) & 1120 & 1.07 & 1.76 & 1.40 & 0.15 \\
\hline KYP (in deg) & 1120 & -27.00 & 70.00 & 32.76 & 10.63 \\
\hline LOR (in deg) & 1120 & 25.00 & 81.00 & 34.13 & 11.66 \\
\hline SCO (in deg) & 1120 & 5.00 & 25.00 & 6.43 & 3.06 \\
\hline APBB (in kg) & 1120 & 5.10 & 23.60 & 11.06 & 3.19 \\
\hline RPBB (in \%) & 1120 & 0.11 & 0.53 & 0.31 & 0.06 \\
\hline APQF (in kg) & 1120 & 4.30 & 31.00 & 13.38 & 3.97 \\
\hline RPQF (in \%) & 1120 & 0.08 & 0.65 & 0.38 & 0.08 \\
\hline Tmax (in ms) & 1120 & 70.00 & 635.00 & 272.11 & 87.29 \\
\hline Fmax (in N) & 1120 & 13.10 & 1766.00 & 422.32 & 184.14 \\
\hline IEP (in N/ms) & 1120 & 0.08 & 13.08 & 1.78 & 1.17 \\
\hline RC (in N/(ms*k)) & 1120 & 0.01 & 0.26 & 0.05 & 0.03 \\
\hline \hline
\end{tabular}

Table 2. Incidence of the spinal and feet disorders of the total sample $(N=1120)$ in frequencies and in percent

\begin{tabular}{c|c|c|c}
\hline \hline \multicolumn{2}{c|}{} & $\begin{array}{c}\text { Number of } \\
\text { respondents }\end{array}$ & $\%$ \\
\hline \multirow{4}{*}{ Gender } & Male & 549 & 48.9 \\
\cline { 2 - 4 } & Female & 571 & 51.1 \\
\cline { 2 - 4 } & Total & 1120 & 100.0 \\
\hline \multirow{4}{*}{ KYP } & No & 861 & 76.9 \\
\cline { 2 - 4 } & Yes & 259 & 23.1 \\
\cline { 2 - 4 } & Total & 1120 & 100.0 \\
\hline \multirow{4}{*}{ LOR } & No & 603 & 53.8 \\
\cline { 2 - 4 } & Yes & 517 & 46.2 \\
\cline { 2 - 4 } & Total & 1120 & 100.0 \\
\hline \multirow{4}{*}{ SCO } & No & 181 & 16.2 \\
\cline { 2 - 4 } & Yes & 939 & 83.8 \\
\cline { 2 - 4 } & Total & 1120 & 100.0 \\
\hline \multirow{5}{*}{ RF } & No & 177 & 15.8 \\
\cline { 2 - 4 } & 2 & 618 & 55.2 \\
\cline { 2 - 4 } & 3 & 272 & 24.3 \\
\cline { 2 - 4 } & 4 & 53 & 4.7 \\
\cline { 2 - 4 } & Total & 1120 & 100.0 \\
\hline \multirow{5}{*}{ LF } & No & 217 & 19.3 \\
\cline { 2 - 4 } & 2 & 590 & 52.7 \\
\cline { 2 - 4 } & 3 & 253 & 22.6 \\
\cline { 2 - 4 } & 4 & 60 & 5.4 \\
\cline { 2 - 4 } & Total & 1120 & 100.0 \\
\hline \hline \multirow{4}{*}{} & & & \\
\hline \hline
\end{tabular}




\begin{tabular}{|c|c|c|c|c|c|c|c|c|c|}
\hline & 10 & 20 & 30 & 40 & 50 & 60 & 70 & 80 & 90 \\
\hline KYF & & & 23.1 & & & & & & \\
\hline LOR & & & & & 46.2 & & & & \\
\hline SCO & & & & & & & & & 83.8 \\
\hline RF 2 & & & & & & 55.2 & & & \\
\hline RF 3 & & & 24.3 & & & & & & \\
\hline RF4 & 4.7 & & & & & & & & \\
\hline LF2 & & & & & & 2.7 & & & \\
\hline LF3 & & & 22.6 & & & & & & \\
\hline LF4 & 5.4 & & & & & & & & \\
\hline
\end{tabular}

Graph 1. Incidence of the spinal and feet disorders of the total sample $(N=1,120)$ in percent

power status in dynamic conditions (Fmax and IEP); c) feet status (LF and RF) and muscle power status in static conditions (APQF);

2) a significant negative correlation between a) sagittal postural status (KYP) and muscle power status in static conditions (RPQF and RPBB; b) feet status (LF and RF) and muscle power status in static conditions (RPBB and RPQF); c) feet status (LF and $\mathrm{RF}$ ) and muscle power status in dynamic conditions (RC).

\section{DISCUSSION}

Actual research is characterized by a high determined incidence of postural disorders and relatively poor muscle power status in primary school children.

High incidence of spinal disorders determined in our research, with $83.8 \%$ of children having scoliosis, is comparable with data of Lazić et al. (14) who determined somewhat lower, but still high incidence of scoliosis (67\%) among children and adolescents $(\mathrm{N}=100)$ in Belgrade (14). We determined $23.1 \%$ of children with hyperkyphosis and $46.2 \%$ with hyperlordosis, versus $27 \%$ and $6 \%$ (respectively) determined in research of Lazić et al. (14).

Dragić et al. (15), determined an incidence of $83.9 \%$ of children with some kind of postural disorder in the sagittal plane. The sample consisted of 435 young school age children at the territory of Vršac.

Kolarová et al. (16) determined large percentages of the existing postural disorders: $70 \%$ of children was diagnosed with fallen arch of the foot, more than $30 \%$ of children with cervical hyper- lordosis, thoracal hyperkyphosis and lumbar hyperlordosis, and $13 \%$ of children with scoliosis.

Adolescent idiopathic scoliosis is characterized by disproportion in the level of muscular force and bone length. Deterioration and progression can reach 10 degrees at the annual level, accompanied by stormy hormonal changes (17).

Previous clinical examinations proved the existence of the degenerative changes in dorsal muscle fibers on each side of the spinal column caused by scoliosis, characterized by distinct fatty tissue overgrowth of the transverse-spinous muscles on the concave side of the curvature in the apex area of the primary scoliosis. Posture type, scoliosis degree and location significantly influence the effectiveness of the motion performance, but do not influence to a great extent changes in the trunk flexors' and extensors' power (18).

High incidence of feet disorders determined in our research, with $82.4 \%$ (mean value of the sum of $80.7 \%$ and $84.2 \%$ ) of children having flat feet of the second, third or forth degree, is comparable with data of Kolarová et al. (16), who found flat feet occurrence of $65 \%$, determined on a sample of 311 primary school children from 16 Slovakian districts.

On the total sample of 2,083 Taiwanese children aged between 7 and 12 years, 59\% of children were diagnosed with flat feet (19).

Flat feet are associated not only to knee and hip injuries and low back pain (20), but to the lower muscle activity and motor control (21), resulting with distorted and inaccurate movement.

By understanding muscular imbalance associated with functional decline, physicians can prescribe specific corrective exercises and appropri- 
ate physical activity, as both prevention and treatment tool (22).

When appropriate physical activity is concerned, relatively poor muscle power status observed in our research emerged from low levels of physical activity of children from the municipality of Knjaževac.

Research conducted in Serbia over the past decades revealed, despite great methodological limitations, a linear decrement in motor capacities of children (23).

By analyzing the level of static power and the morphological development of children with lordotic and kyphotic postural disorders and flat feet, Andrašić et al. (24) found weaker muscles of the abdominal wall, accompanied with the abdominal protrusion in children with lordotic poor posture, and underdeveloped back musculature in children with kyphotic poor posture, compared to children with flat feet (24). Despite different tests used in our research, compared to "folding endurance" test performed by Andrašić et al. (24), the appearance of children's abdominal and back musculature is similar: it is weak and underdeveloped.

It is assumed that the type of sport activity, the time and volume of the engagement can influence the type of musculoskeletal response. Hence, not every sports activity has proven to be appropriate and beneficial for children in relation to their postural status (17), especially when unilateral sport activities are concerned (25). Knowing the positive effect of swimming on postural status, the municipality of Knjaževac provided all children and adolescents with determined postural disorders free and guided use of the swimming pool, under the supervision of a physicians and PE teachers, employees of the Sports Association of the municipality of Knjaževac. Programmed swimming activities are performed during the whole year and are combined with the above mentioned corrective programs.

All determined postural disorders in the cohort of children of the municipality of Knjaževac are at the early functional stage, and are susceptible to the simultaneous and combined action of internal and external mechanical forces that are provided through prolonged and programmed corrective exercise and swimming.
Finally, delayed diagnosis and access to specialised corrective system of exercise and appropriate physical activity at the youngest possible age can be detrimental to long-term negative outcomes. Postural disorders prevention should be considered in line with resources, needs, and priorities (26).

\section{CONCLUSION}

Results revealed poor postural and muscle power status in primary school children.

The determined correlations between the indicators of postural and muscle power status point to possible kinetic chain reaction causing the disruption of the normal postural status.

Postural disorders are functional in nature and are reducible by appropriate corrective exercises programmes application and augmented level of proper physical activity that is beneficial to relatively poor muscle power status.

Those programmes and activities are being guided and implemented by physicians and PE teachers in the municipality of Knjaževac.

Research contribution reflected in the fact that the obtained results contributed to better understanding of the correlation between postural disorders and muscle power in primary school children.

Two main methodological shortcomings of the research relate to deficiency of the measuring instruments, i.e., the fact that the postural status investigation was possible to conduct in static conditions only, and the impossibility to determine the postural and muscle power status simultaneously in different regions of the body.

\section{Acknowledgements}

The authors wish to acknowledge the cooperation of the employees at the Sports Association of the municipality of Knjaževac, who made this work possible, supported by a grant of the Ministry of Education and Science of the Republic of Serbia within project titled „The differences and the influences of the maximum muscle strength on the bone mineral density between athletes and non-athletes of high school population“ (no. OI179024). 


\section{References}

1. Paskaleva R, Ivanova, V., Pavlova, V. Increasing the motor activity for prevention of spinal deformities in children's of pre-school age. Trakia J Sci 2018; 16( Suppl 1): 29-34.

https://doi.org/10.15547/tjs.2018.s.01.006

2. Aroeira RMC, Estevam B, Pertence AEM, et al. Non-invasive methods of computer vision in the posture evaluation of adolescent idiopathic scoliosis. J Bodyw Mov Ther 2016; 20(4): 832-43. https://doi.org/10.1016/j.jbmt.2016.02.004

3. Kowalski IM, Protasiewicz-Fałdowska $H_{\text {, }}$ Dwornik $\mathrm{M}$, et al. Objective parallel-forms reliability assessment of 3 dimension real time body posture screening tests. BMC Pediatr 2014; 14(1): 221.

https://doi.org/10.1186/1471-2431-14-221

4. Bićanin P, Milenković S, Radovanović D, et al. Postural disorders in preschool children in relation to gender. FU Phys Ed Sport 2017; 15(1): 1-10.

http://casopisi.junis.ni.ac.rs/index.php/FUPhysEd Sport/article/view/2756

5. Ludwig O. Interrelationship between postural balance and body posture in children and adolescents. J Phys Ther Sci. 2017; 29(7): 1154-8. https://doi.org/10.1589/jpts.29.1154

6. Jorgić B, Milenković M, Ždrale S, et al. Spinal cord posture in the sagittal plane among young schoolchildren residing in the area of Knjaževac. FU Phys Ed Sport 2016; 13(2): 311-8.

7. Mannion AF, Knecht K, Balaban G, et al. A new skin-surface device for measuring the curvature and global and segmental ranges of motion of the spine: Reliability of measurements and comparison with data reviewed from the literature. Eur Spine J 2004; 13(2): 122-36. https://doi.org/10.1007/s00586-003-0618-8
8. Post RB, Leferink VJ. Spinal mobility: Sagittal range of motion measured with the Spinal Mouse, a new non-invasive device. Arch Orthop Trauma Surg 2004; 124(3): 187-92. https://doi.org/10.1007/s00402-004-0641-1

9. Sheehan DD, Grayhack J. Pediatric Scoliosis and Kyphosis: An Overview of diagnosis, management, and surgical treatment. Pediatr Ann 2017; 46(12): e472-e480. https://doi.org/10.3928/19382359-20171113-01

10. Grossman DC, Curry SJ, Owens DK, et al. Screening for adolescent idiopathic scoliosis: US preventive services task force recommendation statement. JAMA 2018; 319(2): 165-72. https://doi.org/10.1001/jama.2017.19342

11. Been E, Kalichman L. Lumbar lordosis. The Spine Journal 2014; 14(1): 87-97. https://doi.org/10.1016/j.spinee.2013.07.464

12. Milenković S., Stanković R., Đorđević S. Metodologija korektivnog vežbanja (Methodology of the corrective exercise). Sports Association of the municipality Knjaževac, 2018. In Serbian

13. Petrović M, Obradović B, Golik-Perić D, et al. Jumping abilities are not related to foot shape. FU Phys Ed Sport 2013; 11(3): 299-305.

14. Lazić I, Petronić-Marković I, Sinđić-Antunović S, et al. Influence of physical activity on prevention and occurrence of spinal disorders in children during development. Vojnosanit Pregl 2021; https//doi.org/10.2298/VSP190702127L

15. Dragić B, Midić D, Midić M. Posturalni poremećaji na kiĉmenom stubu u sagitalnoj ravni kod školske dece (Postural disorders of the spinal cord in the sagittal plane in schoolchildren). Godišnjak Učiteljskog fakulteta u Vršcu 2012; 3: 279-90. In Serbian 
16. Kolarová M, Kutiš $\mathrm{P}$, Rusnák R, et al. Analysis of body segments and postural state in school children. Neuro Endocrinol Lett 2019; 40(Suppl.1): 17-23.

17. Jandrić S. Scoliosis and sport. SportLogia 2015; 11(1), 1-10.

https://doi.org/10.5550/sgia.151101.en.001I

18. Anwajler J, Skrzek A, Mraz M, et al. The size of physiological spinal curvatures and functional parameters of trunk muscles in children with idiopathic scoliosis. Isokinet Exerc Sci 2006; 14(3): 251-9.

https://doi.org/10.3233/IES-2006-0234

19. Chang JH, Wang SH, Kuo CL, et al. Prevalence of flexible flatfoot in Taiwanese school-aged children in relation to obesity, gender, and age. Eur J Pediatr 2010; 169(4): 447-52.

https://doi.org/10.1007/s00431-009-1050-9

20. Kothari A, Dixon PC, Stebbins J, et al. Are flexible flat feet associated with proximal joint problems in children?. Gait Posture 2016; 45: 204-10. https://doi.org/10.1016/j.gaitpost.2016.02.008

21. Madadi-Shad M, Jafarnezhadgero AA, Sheikhalizade $\mathrm{H}$, et al. Effect of a corrective exercise program on gait kinetics and muscle activities in older adults with both low back pain and pronated feet: A double-blind, randomized controlled trial. Gait Posture 2020; 76: 339-45.

https://doi.org/10.1016/j.gaitpost.2019.12.026

22. Tomašević-Todorović S. Physiotherapy aspect of diagnosis and treatment of postural disorders. EQOL 2014; 6(1): 7-15.

23. Radovanović D, Ignjatović A. Secular trend in motor skills of children and adolescents in Serbia. Prev Ped 2020; 6(1-2). (In Serbian)

24. Andrašić $\mathrm{S}$, Milić $\mathrm{Z}$, Cvetković $\mathrm{M}$, et al. Relations between biomechanical parameters and static power of arms in children with disturbed posture. Sport Mont 2017; 15(1): 23-6.

25. Bang SH, Yoon JG, Park JM. Effects of core balance training on Cobb angle, isokinetic torque, and balance in unilateral handed athletes. J Exerc Rehabil 2020; 16(3): 279-85.

https://doi.org/10.12965/jer.2040266.133

26. Green BN, Johnson CD, Haldeman S, et al. The Global Spine Care Initiative: Public health and prevention interventions for common spine disorders in low-and middle-income communities. Eur Spine J 2018; 27(6): 838-50. https://doi.org/10.1007/s00586-018-5635-8 


\title{
Posturalni deformiteti i snaga mišića dece osnovnoškolskog uzrasta
}

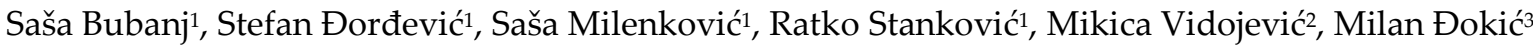 \\ ${ }^{1}$ Univerzitet u Nišu, Fakultet sporta i fizičkog vaspitanja, Niš, Srbija \\ ${ }^{2}$ Dom zdravlja u Knjaževcu, Knjaževac, Srbija \\ ${ }^{3}$ Opština Knjaževac, Knjaževac, Srbija
}

\section{SAŽETAK}

Cilj istraživanja je doprinos boljem razumevanju povezanosti posturalnih deformiteta i snage mišića dece osnovnoškolskog uzrasta. Uzorak ispitanika sačinjavalo je 1120 dece, uzrasta od 7 do 12 godina (549 dečaka i 571 devojčica), učenika osnovnih škola sa teritorije opštine Knjaževac. U proceni posturalnog statusa kičmenog stuba, u frontalnoj i sagitalnoj ravni, korišćen je aparat „Spinal Mouse“ (Švajcarska), dok je u analizi statusa stopala korišćen podoskop „Pedic“ (Mađarska). U analizi snage mišića korišćeni su ručni dinamometar "Lafayette“ (SAD) i tenziometrijska platforma sile "Vernier Force Plate" (SAD). Status kičmenog stuba i stopala utvrđivan je u statičkim uslovima, sa decom u uspravnom, stojećem položaju. Status snage mišića utvrđivan je u statičkim (kliničar je primenjivao mišićnu silu na dominantni gornji ekstremitet deteta, pokušavajući da savlada ili "slomi“ detetov otpor mišića) i dinamičkim uslovima (skok sa počučnjem). U obradi podataka korišćene su deskriptivna statistika i korelaciona analiza, upotrebom softvera SPSS, verzija 24. Rezultatima su utvrđeni loš posturalni i mišićni status i korelacije koje ukazuju na moguć kinetički lanac reakcija, koji uzrokuje poremećaj normalnog posturalnog statusa dece osnovnoškolskog uzrasta. Utvrđene posturalne poremećaje karakteriše rani funkcionalni stadijum, koji može da se redukuje primenom odgovarajućeg programa korektivnog vežbanja i povećanog nivoa odgovarajuće fizičke aktivnosti. Takve programe i aktivnosti sprovode lekari i nastavnici fizičkog vaspitanja u opštini Knjaževac.

Ključne reči: posturalni status, mišićno-skeletni poremećaji, korektivne vežbe, deca osnovnoškolskog uzrasta 